AsCLePIO. Revista de Historia de la Medicina y de la Ciencia

66 (1), enero-junio 2014, p034

ISSN-L:0210-4466

http://dx.doi.org/10.3989/asclepio.2014.08

\title{
THE MEANING OF "GENERAL PARALYSIS OF THE INSANE" IN VICTORIA, AUSTRALIA; 1886 TO 1906
}

\author{
Phillip Roberts, PhD, MA, B. Eng \\ School of Archaeology \& Anthropology. The Australian National University \\ phil.roberts@anu.edu.au
}

Received: May 28, 2013; Accepted: December 9, 2013.

Citation/Cómo citar este artículo: Roberts, Phillip (2014), "The Meaning of 'General Paralysis of the Insane' in Victoria, Australia; 1886 to 1906", Asclepio 66 (1): p034. doi: http://dx.doi.org/10.3989/asclepio.2014.08

\begin{abstract}
This paper presents a conclusion to the meaning of the historical diagnosis "general paralysis of the insane" in nineteenth century Victorian Registrar General"s reports. Most studies suggest that in the past the diagnosis refers to neuro-syphilis, and while after 1906 this is not disputed, this paper will show that the diagnosis had a much broader meaning incorporating many forms of degenerative brain disease during the study period (Victoria 1886 to 1906). It is acknowledged, however, that the use of this diagnosis may have varied dramatically in the past based on a doctor's education and/or background. This conclusion has been arrived at by analysing both government and general hospital records on the Australian, Victorian population. This paper also presents methods for determining the meaning of obsolete medical diagnoses where the definition is poorly understood.
\end{abstract}

KEY WORDS: "General Paralysis of the Insane"; Neuro-Syphilis; Degenerative Brain Disease; Historical Diagnosis, Nineteenth Century Victoria; Historical Epidemiology.

\section{EL SIGNIFICADO DE “PARÁLISIS GENERAL DEL DEMENTE” EN VICTORIA, AUSTRALIA; 1886-1906}

RESUMEN: En este trabajo presenta una conclusión sobre el significado de la "parálisis general de los locos" como diagnóstico en los informes del Victorian Registrar General durante el siglo XIX. La mayoría de los estudios sugieren que en el pasado el diagnóstico se refiere a la neuro-sífilis, y aunque después de 1906 no se discute, este trabajo mostrará que el diagnóstico tiene un significado mucho más amplio e incorpora muchas formas de enfermedad degenerativa del cerebro durante el período de estudio (Victoria 1886 a 1906). Se reconoce, sin embargo, que el uso de este diagnóstico puede haber variado drásticamente en el pasado dependiendo de la formación y del ambiente médico. Se ha llegado a esta conclusión mediante el análisis de los registros hospitalarios de la población de Victoria, Australia. Este documento también presenta métodos para determinar el significado de los diagnósticos médicos obsoletos cuya definición es confusa.

PALABRAS CLAVE: «Parálisis General del Loco»; Neuro-Sífilis; Enfermedad Degenerativa del Cerebro; El Diagnóstico Histórico, Del Siglo XIX Victoria; Epidemiología Histórica.

Copyright: (c) 2014 CSIC. This is an open-access article distributed under the terms of the Creative Commons Attribution-Non Commercial (by-nc) Spain 3.0 License. 


\section{INTRODUCTION}

For much of the twentieth century, the diagnosis of "general paralysis of the insane" ("GPI") was understood to be a possible outcome of neuro-syphilis and this interpretation has been widely used in neurological and medical journals in the twentieth century (Fraser 1981, Dawson-Butterworth and Heathcote 1970-, Laird 1962, Nicol 1956, Galbraith 1938). This statement is further supported by evidence provided by Cumpston and Lewis (1989:270), who discuss that in 1911, 59 out of 99 "idiot" Australian children showed a positive Wassermann reaction. There is therefore the potential for one to argue that the diagnosis "GPI" also occurred as a consequence of neuro-syphilis in the nineteenth century. This has been argued by Davis (2008) to be the case in Scotland from 1880 to 1930, but it will be shown that this assumption does not fit with the analysis of the data derived from the study period (1886 to 1906) of this paper. This paper presents these results and makes some discussion into why so much confusion exists surrounding the diagnosis of GPI in the nineteenth century.

To further this argument, an aim of this project is to determine the cause of a GPI diagnosis in a "normal" patient, as defined in epidemiological studies (Bonita et al 2006:134).

It is an important consideration that "insanity" may have been over-diagnosed during the study period; Malcolm (2009:49) quotes Henry Burdett who in 1891 said "lunacy is more general in Victoria than in the other Australian colonies" and Ephraim Zox (chairman of the 1884-6 Victorian Royal Commission on Asylums) who said of Victoria that it was "the maddest place in the world".

\section{SEPARATION OF DISEASE AND DIAGNOSIS}

Cunningham (2002) has made an observation that disease is not only a pathological reality but also a social construction based on human social relations and habits, a statement supported by Peset (2002:7) and Tedebrand (2002:94) as examples. The author"s research presents a modification to this and is an important methodological foundation of this paper. In this paper the position is taken that disease is a pathological reality, and that the disease itself is not altered just because the people observing it did not understand it. In reality, it is the definition of a disease which is not easily defined and is never described perfectly. However, we do know that disease exists. The diagnosis (including classification and described signs and symptoms) is what is described as a result is a social construction based on human understanding, social relations and on the habits of the population in which the disease existed. Diagnosis is therefore the artefact not only of disease but also of the social habits of the affected population. It is the disease classification that is imperfect, and not the disease.

Therefore, disease and diagnosis, although related, are actually different entities, one is a product of a biological reality the other is the scientific, social and/or cultural interpretation of that reality. When conducting an analysis of historical epidemiology what is actually being studied is the frequency of use of the descriptive artefact, not the disease itself. This however presents as a problem as scientific, social and cultural ideas can change over time. Arrizabalaga (2002:57) supports this in that the diagnosis becomes less specific with reduced scientific understanding and therefore the older the information the harder it is to interpret using historical methods only. Therefore the statistical analysis of historical mortality and morbidity data is also important.

\section{ANALYSIS OF THE VICTORIAN REGISTRAR GENERAL'S REPORTS}

The "GPI" diagnosis was not used in the Registrar General's Reports for the entire duration of the publication of those reports (figure 1) and at the times when it was used (from 1886 to 1907), male deaths greatly outnumbered female deaths. Also, the age group whose death was most frequently described using the diagnosis "GPI" (figure 2) were also in the older age ranges and that the diagnosis was reasonably endemic. [Also shown in Figure 2 is that by 1906 the use of this diagnosis dropped dramatically.]

The reasons why the author believes that "GPI" does not refer to a form of neuro-syphilis in the majority of cases within the study period is displayed in Figure 3. This scatter plot displays the correlation between "GPI" mortality and that of "syphilis" for people over 15 years of age (the venereal syphilis cases) as recorded in the Registrar General"s reports. Firstly there is very little correlation between "GPI" and "syphilis" mortality rates, with a Pearson correlation of $r=0.31$. If "GPI" were to in fact refer to mortality from tertiary syphilis, there should be a good correlation with mortality from "syphilis" as they should both be driven by the same underlying causes. This correlation is reduced further to $r=0.01$ by removing the points for 1904, 1905 and 1906, which as discussed in Roberts (2013), relies on potentially unreliable data from the Victorian Registrar General's Reports and appear as outliers in Figure 3.

The second thing that this chart shows is that "GPI" often described nearly twenty times more deaths than "syphilis" in adults (over the age of 15 years). In modern times, neuro-syphilis occurs in approximately $8 \%$ of tertiary syphilis cases (Tierney and Fitzgerald 1981). Even if there was a chronic under-diagnosis of syphilis, a crude extrapolation of this information 
Figure 1. Male and Female Mortality Rates (per 100,000) for 'Insanity' and 'Insanity (General Paralysis of the Insane)', calculated from the Victorian Registrar Generals' Reports

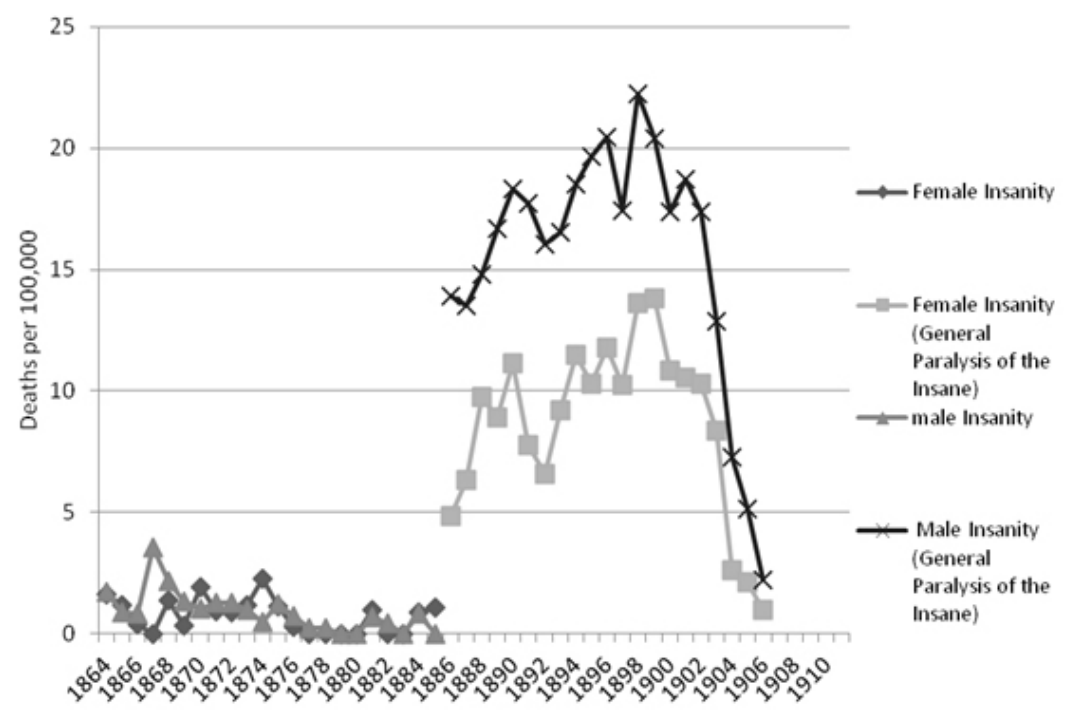

Figure 2. Age/Cause specific death rates (deaths per 100,000) calculated from the Victorian Registrar Generals' Reports for the category 'insanity(general paralysis of the insane) ' for 1891, 1901 and 1906

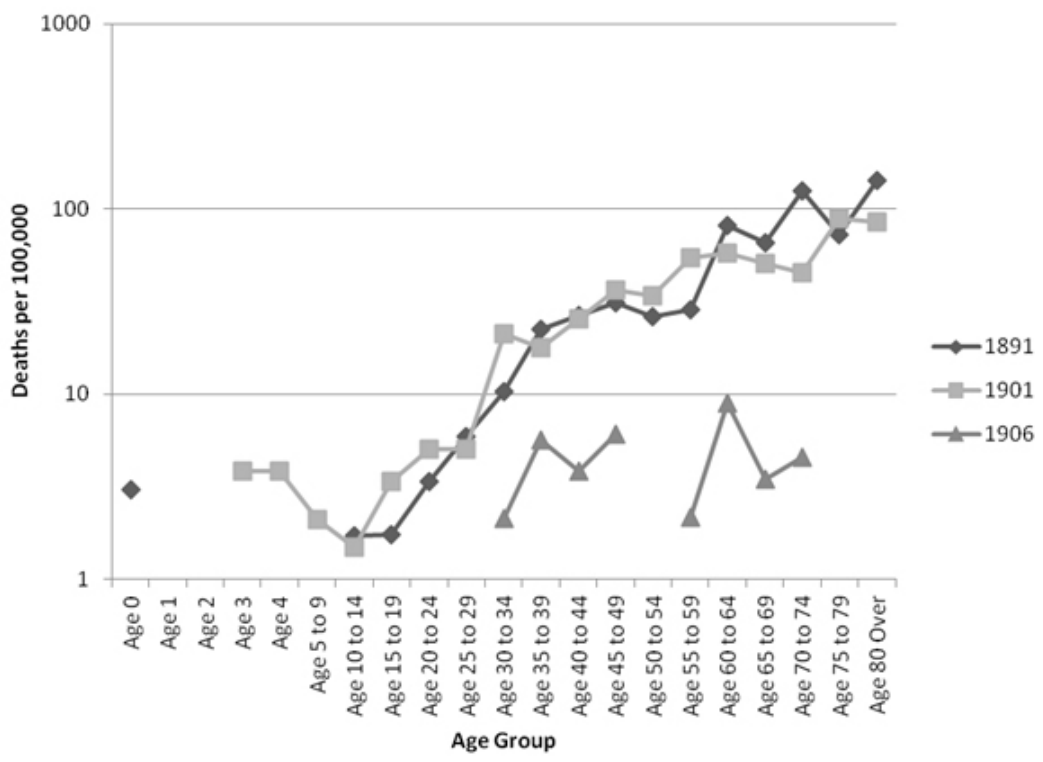

using the mortality rate from "GPI" in nineteenth century Victoria produces an unrealistically high prevalence of syphilis within the study period. For example, crudely, if there are 13 deaths per 100,000 from GPI and $8 \%$ of tertiary syphilis cases develop GPI (which in addition contains the unrealistic assumption that all neuro-syphilis cases became GPI) then tertiary syphilis morbidity in Victoria should be, approximately, 160 per 100,000 . But in reality syphilis deaths, at the same time as GPI was 13 deaths per 100,000, were only 1.2 deaths per 100,000, which would suggest that in Victoria, prior to any effective treatment, the mortality rate for tertiary syphilis was less than $1 \%$.

The diagnosis specific mortality rates for other diagnoses that could be related to insanity or paralysis is shown in figure 4 . The link between the pre and post 1886 classification of insanity is evident in the dramatic change in associated mortality. 
Although the link between the diagnoses is clearly not perfect, the rate of deaths from this cause never rises above 35 deaths per 100,000 in any of the years being studied. In 1853, "insanity" was a more common diagnosis, dropping substantially by 1859 , which appears to parallel the Gold Rush period. This immediately raises the question of mercury poisoning in that period, as mercury amalgams were historically a common method of removing fine gold from gold bearing material (Lynch 2002). Mercury was also often used to treat syphilis as well as a wide variety of other diseases (O"Shea 1990) which has the potential to contribute to morbidity from mental health in the nineteenth century. Unfortunately the extent of this issue will be difficult to test without biochemical analysis.

Figure 3. 'GPI' versus 'Syphilis' over the age of 15 (deaths per 100,000) calculated from Registrar Generals' Reports

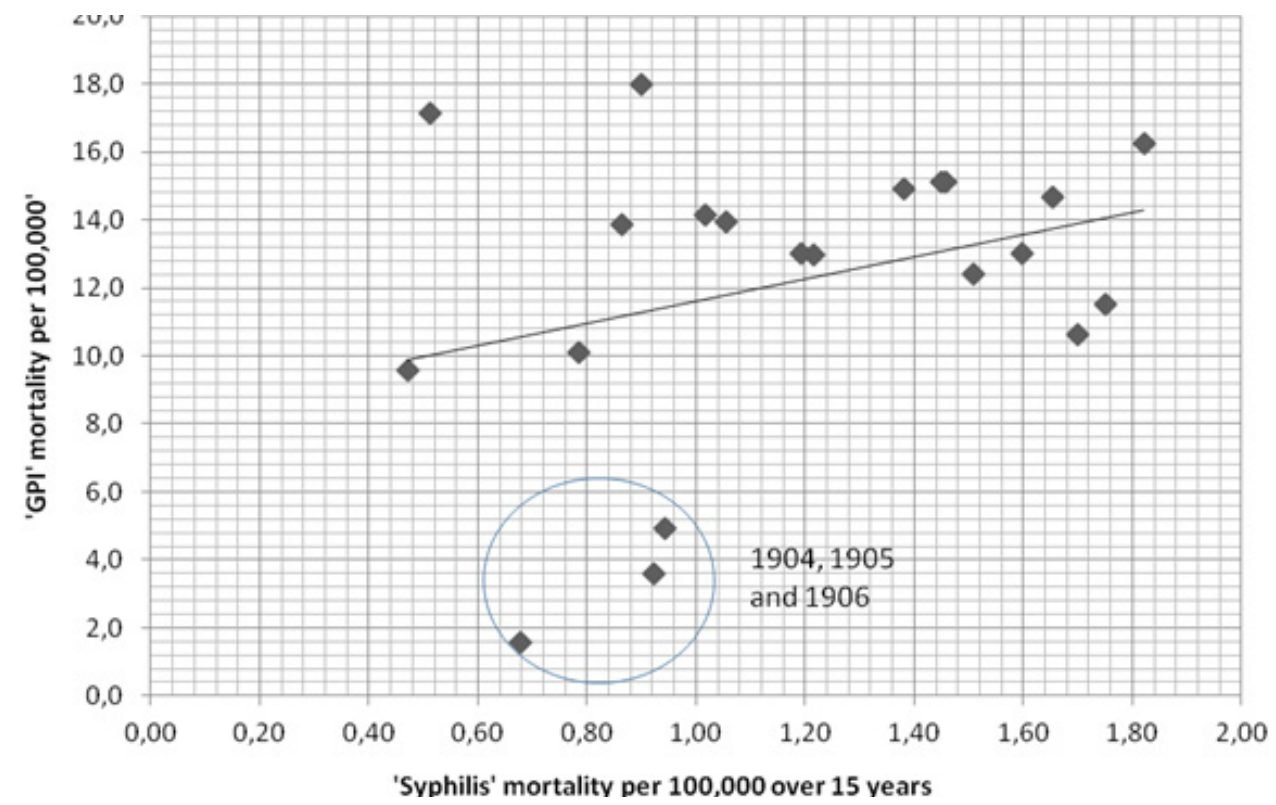

Figure 4. Diagnosis Specific Mortality Rates for diagnoses recorded in the Registrar Generals' Reports from 1853 to 1906 relating to 'insanity' and 'paralysis'

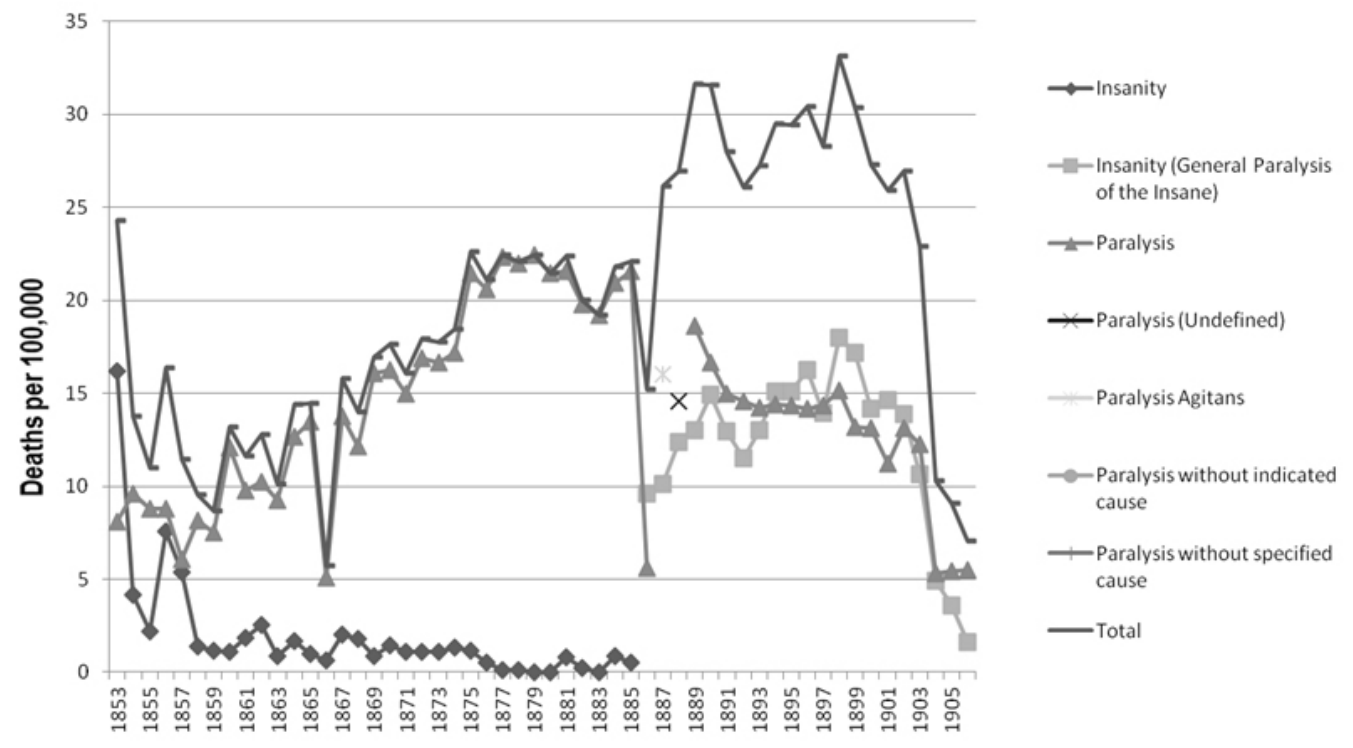




\section{A STUDY OF DIAGNOSES USED IN THE BENDIGO BASE HOSPITAL AND ROYAL MELBOURNE HOSPITAL}

To determine what sorts of symptoms could be associated with a fatal case of "insanity", a key word search was conducted on the administration registrar of the Bendigo Base Hospital $(\mathrm{BBH})^{1}$ and on the Doctor"s Book Index of the Royal Melbourne Hospital $(\mathrm{RMH})^{2}$. Both of these facilities are general hospitals not mental health facilities. Any words referring to an altered mental state of the patient, were sought. The key words identified in the hospital records were delirium, delusion/delusional, insanity/insane, senile/ senility, mental, mania/maniac, hysterical/hysteria, lunacy/lunatic, dementia and melancholia. All cases that included one of these terms (including spelling variations) were selected to make up a sub-population for further study. This group was then assessed for its hospitalised case fatality rate at each hospital, demographic profile and associated symptoms.
It is acknowledged that there is nothing specific that relates these terms to GPI, however the "GPI" diagnosis was not used at all in the $\mathrm{RMH}$ and only in three cases at the $\mathrm{BBH}$ which does not correlate with the mortality rates reported in the Registrar General's reports. This suggests that there was little consistency regarding the use of this diagnosis between institutions. This may account for the degree of confusion surrounding this diagnosis.

The hospitalised case fatality rate for diagnoses that appear to relate to some sort of mental disorder are shown in table 1 . This table was compiled according to the key word searches in both the $\mathrm{BBH}$ and $\mathrm{RMH}$. There is a dramatic difference in rates between the two hospitals in number of cases treated, including in the rate of unstated outcomes, in both the case fatality rate and in the diagnosis rate. In nearly all figures, the $\mathrm{BBH}$ appears to contain the more reliable data.

Table 1. Key words used to create 'insane' population in the BBH and RMH, with associated hospitalised admission fatality proportion (HAFP) and unstated outcome rate

\begin{tabular}{|c|c|c|c|c|c|}
\hline \multicolumn{6}{|c|}{ BBH } \\
\hline Key Word & Cases & Died & $\begin{array}{l}\text { Un-stated } \\
\text { Outcome }\end{array}$ & HAFR & Un-stated Rate \\
\hline Delirium & 4 & 1 & 0 & $25 \%$ & $0 \%$ \\
\hline Delusional & 167 & 1 & 4 & $1 \%$ & $2 \%$ \\
\hline Dementia & 201 & 9 & 17 & $4 \%$ & $8 \%$ \\
\hline Hysteria & 268 & 2 & 8 & $1 \%$ & $3 \%$ \\
\hline Insanity & 267 & 4 & 9 & $1 \%$ & $3 \%$ \\
\hline Lunacy & 63 & 2 & 5 & $3 \%$ & $8 \%$ \\
\hline Mania & 318 & 10 & 15 & $3 \%$ & $5 \%$ \\
\hline Melancholia & 234 & 3 & 11 & $1 \%$ & $5 \%$ \\
\hline Mental & 22 & 0 & 0 & $0 \%$ & $0 \%$ \\
\hline Senility & 567 & 193 & 23 & $34 \%$ & $4 \%$ \\
\hline Total & 1935 & 218 & 81 & $11 \%$ & $4 \%$ \\
\hline
\end{tabular}

\begin{tabular}{|c|c|c|c|c|c|}
\hline \multicolumn{6}{|c|}{ RMH } \\
\hline Key Word & Cases & Died & $\begin{array}{l}\text { Unstated } \\
\text { Outcome }\end{array}$ & HAFR & Unstated Rate \\
\hline Delirium & 53 & 19 & 11 & $36 \%$ & $21 \%$ \\
\hline Delusional & 2 & 0 & 1 & $0 \%$ & $50 \%$ \\
\hline Dementia & 15 & 3 & 1 & $20 \%$ & $7 \%$ \\
\hline Hysteria & 157 & 2 & 35 & $1 \%$ & $22 \%$ \\
\hline Insanity & 36 & 9 & 9 & $25 \%$ & $25 \%$ \\
\hline Lunacy & 10 & 2 & 1 & $20 \%$ & $10 \%$ \\
\hline Mania & 17 & 1 & 3 & $6 \%$ & $18 \%$ \\
\hline Melancholia & 18 & 0 & 3 & $0 \%$ & $17 \%$ \\
\hline Mental & 21 & 2 & 5 & $10 \%$ & $24 \%$ \\
\hline Senility & 18 & 4 & 2 & $22 \%$ & $11 \%$ \\
\hline Total & 345 & 42 & 70 & $12 \%$ & $20 \%$ \\
\hline
\end{tabular}


The $\mathrm{BBH}$ has produced a much larger population in this case study, which is believed to be a result of the administration practices between the two hospitals rather than there being more cases of mental disorders in Bendigo. The RMH could easily transfer patients to the mental health facility at Yarra Bend, where the BBH could not. The terms "delirium" and "hysteria" might not have been included in the analysis, as they appear to refer to a symptom of fever or head injury, and a description of the emotional state of the patient, respectively, rather than a mental illness. They have not been removed in this instance in order to demonstrate the method used. If these two diagnoses were to be removed, however, the number of cases of mental illness admitted would be reduced; indeed the $\mathrm{RMH}$ cases are further reduced by approximately another two thirds, highlighting that the $\mathrm{RMH}$ rarely admitted mentally ill patients.

$\mathrm{RMH}$ also has a much larger rate of unstated outcomes when compared to the $\mathrm{BBH}$ records. This is probably due to the intention of the source data; RMH doctor's books were not necessarily concerned with patient administration, whereas this was the primary role of the $\mathrm{BBH}$ administration records. The associated case fatality rate against the chosen key words are often much higher in the RMH: although not fully understood, this is thought to be due to patients being admitted to the RMH at a later stage of the disease progress. Due to these issues, the results from the RMH will be considered less reliable that those from the $\mathrm{BBH}$ in this case.

The highest Hospitalised Admission Fatality Proportion (HAFP) for these diagnoses is "senility" in the $\mathrm{BBH}$, and is much higher than the other key diagnoses. "Delirium", also has a higher HAFP as stated this would be expected where the term is linked to fever and other causes.

A count of other symptoms and descriptions of patients who died in either the $\mathrm{RMH}$ or the $\mathrm{BBH}$ is displayed in table 2 . In the BBH there were 218 deaths in the selected sub-population. The most commonly associated symptoms, in order of frequently reported, are "debility", heart disease, pulmonary involvement (asthma, bronchitis, pneumonia, "phthisis") diarrhoea/ dysentery and gangrene. Gangrene as an associated symptom of "insanity" or often more specifically a "senile" case, is particularly interesting as it is thought that this may be linked to diabetes, bed sores or other disorders of blood circulation, which is not surprising in the older aged population. However, of all of the cases where the patient died at both hospitals only one case at the RMH associates syphilis with a death.

Table 2. Counts of symptoms associated with a fatal case in the selected sub-population at the BBH and the RMH

\begin{tabular}{|c|c|c|c|c|}
\hline & \multicolumn{2}{|c|}{ BBH } & \multicolumn{2}{|c|}{ RMH } \\
\hline & \multicolumn{2}{|c|}{ Total cases $=218$} & \multicolumn{2}{|c|}{ Total cases $=42$} \\
\hline Debility & 64 & $29.4 \%$ & 3 & $7.1 \%$ \\
\hline Diarrhoea/Dysentery & 13 & $6.0 \%$ & & \\
\hline Exposure/ Exhaustion & 4 & $1.8 \%$ & & \\
\hline Fever & & & 3 & $7.1 \%$ \\
\hline Gangrene & 11 & $5.1 \%$ & & \\
\hline Heart Disease & 17 & $7.8 \%$ & & \\
\hline Infection & 3 & $1.4 \%$ & & \\
\hline Pain & & & 3 & $7.1 \%$ \\
\hline Pneumonia & 10 & $4.6 \%$ & & \\
\hline Pulmonary Involvement & 6 & $2.8 \%$ & 5 & $11.9 \%$ \\
\hline Trauma & 4 & $1.8 \%$ & & \\
\hline \multicolumn{5}{|c|}{ Additionally: } \\
\hline$B B H$ & & & & \\
\hline
\end{tabular}

1 case each with mention of alcohol, back pain, bed sores, a chronic illness, destitute, delirium tremens, enlarged prostate, epilepsy, fever, influenza, kidney involvement, skin condition, stroke and throat complaint.

2 cases each with mention of an acute onset, a brain injury, pregnancy, and ulcer

1 case each with mention of an acute onset, alcohol, delirium tremens, 'dyspnoea', epilepsy, constipation, gangrene, a gynaecological disorder, haematemesis, heart disease, incontinence, liver involvement, paralysis, parasites and syphilis

2 cases each with mention of arthritis, chronic condition, diarrhoea, fits/convulsions, nonspecific infection, lung condition, trauma, tumour and ulcer 


\section{LITERATURE REVIEW}

A number of previous studies have suggested that there was a purposeful misdiagnosis of tertiary syphilis as "GPI". Lewis (1998:64), for example, suggests that to get around hospital administration restrictions, some venereal disease patients were treated "virtually", that is, admitted for a phantom complaint but treated for their actual disease. However, Lewis's data on set on Victoria only starts in 1907. The author does not dispute that "GPI" probably did refer to a form of neurosyphilis after the revolution in mental health from the 1880 s and through to the first decade of the 1900s. It is for the majority of the nineteenth century in Victoria that this association is overstated. The association was also debated in the nineteenth century. Rudolf Virchow rejected the idea that syphilis was the primary cause of "GPI" in 1898 (Lewis 1998:69), although other nineteenth century researchers such as Jaspersen (1874) and Fournier (1894) have claimed that the primary cause of the "GPI" diagnosis was syphilis (Lewis 1998:70).

It is entirely probable that deaths in the nineteenth century attributed to GPI are a large number of conditions. This proposition is supported by discussions regarding GPI by Sibbald in Quain (1886:531). Sibbald (1886) defines the diagnosis of "GPI" as: "a gradual loss of power of coordinated movement, accompanied by gradually increasing mental disturbance and decay." Kraepelin (1904:190-199) case studies of GPI supports this reference with additional symptoms such as loss of memory, impaired pain responses and reflex action. These definitions are quite broad and Sibbald (1886:531) further suggests that the "general paralysis of the brain" may be brought on by:

....excessive mental labour, severe anxiety, by alcoholic or venereal excess, or by any prolonged strain upon the mental organisation. It may also be induced by a blow or other direct injury to the head. Hereditary predisposition is probably not without influence in its production; ..... the disease most frequently attacks persons who have previously been apparently in the enjoyment of vigorous health.

Others such as R. von Kraft-Ebing (1877) cited factors such as heredity, menopause, alcoholism, excessive cold or heat, head trauma, and smoking. A.B. Morel (who introduced the doctrine of degeneration) indicated in 1857 that mental degeneration could be caused by alcoholism, social conditions, temperament or congenital defects (Lewis 1998:69). Grant (1897) also describes six cases of GPI all of which appear to have had different causes. This nineteenth century discussion does not preclude neuro-syphilis as a contributing factor to mortality given as "GPI", because "venereal excess" is included as a cause. But it also does not eliminate numerous other mental disorders, highlighting that the diagnosis had a much broader meaning in the nineteenth century.
Baillarger 1883 identifies three types of "general paralysis of the insane" these being: manic-ambitious, melancholic-hypochondriac and dementia (Baillarger 1883). In 1883, Baillarger identified "paralytic insanity" and "paralytic dementia" as separate diseases because of the occurrence of cerebral lesions and their relationship to behaviour (Baillarger 1883). This suggests that for Baillarger there was a refinement at this point for the GPI diagnosis, through observation the single diagnosis is split into five different diagnoses. He concluded that patients who had symptoms associated with "GPI", but who did not present with lesions, the causative disease must have had a different origin (Berrios 1985). Baillarger"s work resulted in the single cause hypothesis of the diagnosis "GPI" being removed in the late 1880 s and various new diagnoses beginning to appear.

Degenerative disorders of the brain were beginning to be described in the nineteenth century which may further explain the evolution of the diagnostic meaning of "GPI". Of those listed, Parkinson"s disease was the first to be described in 1817 by James Parkinson (Patten 2003), some 23 years before the study period. However, during the nineteenth century the disease was referred to as "paralysis agitans". It is important to note that this term replaced "GPI" in the Victorian Registrar General's reports in 1886 (Figure 4).

Stroke is another, obvious, disease that make alter a person's mental state and impair motor function. Stroke was described in the nineteenth century as "apoplexy", a description usually thought to mean bleeding into an organ (Poirier and Derouesne 2003). The brain is generally considered as the default where no other organ is mentioned (Quain 1886). It is thought by this author, however, that a diagnosis of "apoplexy" would describe the more overt symptoms of stroke, or where there is bleeding evident in the brain at autopsy. Although it is acknowledged that it is unlikely that sudden and dramatic brain damage resulting from a major stroke would have been misdiagnosed as "insanity" or "paralysis", personality change resulting from hypertensive brain injury or because of multi-infarct dementia, however, may not have been as obvious to nineteenth century physicians. Hypertensive brain injury or multi-infarct dementia therefore have been included in the more generic description of "GPI" in the nineteenth century. Support for this comes from Dr P. Smith (1873:42) who describes typical post mortem results of an "insane" patient admitted to mental asylums in Victoria who died soon after admission as follows:

An examination of the brain shows thickening of the brain membranes, changes in the blood-vessels, marks of absorption of old clots, \&c, which must have existed for a long time prior to death, and which during life must have given rise to symptoms which to any careful observer must have been most significant. 
The late nineteenth and early twentieth centuries saw great advances in disease diagnosis. Multiple Sclerosis was also described quite early in the nineteenth century, by Jean-Martin Charcot in 1835 (Compston 1988). George Huntington described Huntington's Disease in 1872 (Devor 2003), while Arnold Pick described Pick"s Disease in 1892 (Amano and Iseki 1999) and 1906 was the first time that pathology and clinical symptoms of pre-senile dementias, such as Alzheimer's Disease, were described by Alois Alzheimer (Kiple 2003). Harvey Cushing's work on Cushing's Disease started in 1901 at John Hopkins University (Greenblait 2003). Kraepelin's fifth edition of Psychiatry was published in 1896 (Pasamanick 1959). What this also shows that for much of the nineteenth century most of the degenerative brain diseases had also not been described. Deaths associated with the pathological reality of these diseases must have been classified somehow prior to their discovery and "GPI" seems the most likely contender considering its high associated mortality rate.

In 1904, Kraepelin gave a lecture series on mental illness characterising a large number of disease types; lecture XX was on GPI (Kraepelin 1904). Chronologically this lecture series represents a high water mark in the revolution in mental health study. It was after this when medical diagnoses associated with mental health began to become more specific.

The years 1906 and 1907 are important in this study as they mark the year when "GPI" stopped being used by the Victorian Registrar General and when the Lewis (1988) study starts. Lewis concluded that "GPI" referred to neuro-syphilis in Australia.

Some support for this observation comes from the United States. Wickman (2006:697-8) observed that in nineteenth century Virginia, dementia was diagnosed and treated as a form of mental "derangement" and its sufferers treated as "imbeciles". In addition, Superintendent William A. White of the U.S.A. Government Hospital for the Insane, described the three main forms of insanity in American hospitals in 1907 being "manic depressive psychosis", "involutional melancholia" and "dementia precox". This again demonstrates that dementia was considered a form of insanity in the nineteenth century (Hirsbein 2009:710).

This historical analysis therefore promotes the idea that prior to this revolution in degenerative brain disease, "GPI" was a generic term for the dementia illnesses and degenerative brain disease, regardless of the cause. This was progressively refined as new diseases were described, leaving syphilis as the primary cause at the start of the twentieth century.

\section{SUMMARY OF RESULTS}

From the evidence presented in the preceding sections, it can be inferred that a typical patient who was described in the Victorian Registrar General's reports as having GPI, was elderly and nearly twice as often male. In addition, the underlying cause appears to have been endemic and killed 20 people per 100,000 annually. Within the study period, this mortality rate is comparable with causes of death such "pulmonary apoplexy", "tubercular meningitis" and the combined accidents of childbirth, and was higher than mortality described as "cholera". In the hospital records, those who died with a diagnosis that was associated with a mental illness were not generally associated with syphilis (one case only). In contrast their death was associated with observations of "debility", "heart disease", "diarrhoea" and "gangrene". The GPI diagnosis was however rare in both hospitals, which contradicts the mortality rate reported in the Registrar General's reports.

The combination of this epidemiological study and a review of the historical literature suggests that dementia was a common cause for a "GPI" diagnosis in the Victorian Registrar General's reports in the study period, but this does not necessarily hold true for the hospital records. This is supported by the history of the development of understanding dementia illness in the late nineteenth century and early twentieth century.

When the present study was initiated, heavy metal poisoning was initially considered to be a strong candidate as to the cause of the diagnosis of "insanity", as mercury amalgams were a common method of extracting gold from gold bearing gravel on the Victorian Goldfields. Mercury had also been used as a chemotherapeutic drug since the $15^{\text {th }}$ century O'Shea (1990) and both the Royal Melbourne and Bendigo Hospitals discuss its use in the treatment of syphilis cases during the study period. However, a case of mercury poisoning, as with other chronic heavy metal poisoning, would generally present with a number of other symptoms, including coughing, vomiting, symptoms associated with kidney damage, eye problems and oedema, none of which are mentioned in many cases in the hospital records (ATSDR 2010). Mercury poisoning may have been more important as a cause of an insanity diagnosis in 1853 , however, as the crude mortality rates in Figure 4 show much higher rates of "insanity" in the early 1850 s paralleling the Gold Rush boom years, it is believed that this cause became less important regarding fatal "insanity" as the century progressed.

\section{CONCLUSIONS}

Throughout the twentieth century, "GPI" was understood to be a type of neuro-syphilis, but this meaning appears to have been the result of the refining of other diseases as they were isolated and described, leaving neuro-syphilis as the primary definition in the 
twentieth century in the Registrar General's reports. Neuro-syphilis simply could not have produced the "GPI" data set collected in this study by itself. However, "GPI" was a rare diagnosis in the hospital records which raises further questions regarding this diagnosis as its meaning may have shifted between institutions and regions. This may explain the conclusions of Davis (2008) for Scotland (which contradict this paper) and the debate surrounding the diagnosis. This being that the practice of the use of the diagnosis varied dramatically with a doctor"s education and background. To verify this conclusion data sources from a number of other regions would have to be analysed using a similar method to this paper.

Dementia and other degenerative brain diseases remain the most plausible explanations for the majority of diagnoses of "GPI" in historical medical records in Victoria in the nineteenth century. It is not clear, however, whether the cause for the dementia was a degenerative brain disease, cardio-vascular disease, long term effects of substance abuse, a metabolic disorder or cancer, and possibly even some heavy metal poisonings cases may have been classified as "GPI" by the Registrar General in the mortality records. The author also believes that syphilis did contribute a number of cases to the "GPI" classification but this percentage did not become significant until other diseases were identified and given their own diagnoses.

\section{ACKNOWLEDGEMENTS}

I would like to acknowledge the contributions of the volunteers of the Victorian Genealogical Society and the Australian Institute of Genealogical Studies, specifically my respective contacts Clive Luckman and Rita Hull, for the use of the transcribed databases of the Royal Melbourne and Bendigo Base Hospitals. Also, the support and approval of the Royal Melbourne Hospital and Bendigo Health and the aid of the respective archivists Gabriele Haveaux and David Lloyd is greatly appreciated.

\section{NOTES}

1 The Bendigo Base Hospital administration records contain; the date of admission, the patient"s surname, the patient"s given name, the patient"s occupation, how long the patient had been a resident in the colony, the patient"s religion, the patient"s residence, the patient"s place of birth, next of kin information, next of kin residence, person the patient was recommend by (if applicable), receiving doctor, the complaint or disease, the anaesthetist (if applicable), the surgeon (if applicable), the operation (if applicable), period in hospital, the outcome of the case, date of discharge or outcome, the patients age and any additional comments.
2 The Royal Melbourne Hospital index contains; the outcome of the case, the hospital ward, the doctor"s surname, patient"s name, the date admitted, the age of the patient, the patient"s marital status, the patient"s occupation, the patient"s place of birth, the patient"s residence, the patient"s religion, how long the patient had been a resident in the colony, a brief description of the complaint, the date of discharge, and any comments made by the attending physician.

\section{BIBLIOGRAPHY}

Agency for Toxic Substances and Disease Registry, (2010, January 22), Mercury and Your Health. Retrieved Feburary 2012, from Agency for Toxic Substances and Disease Registry: http://www. atsdr.cdc.gov/mercury/ [consulted in Feb 2012]

Allchin, W. (1882), "Senility.", In : R. Quain, A Dictionary of Medicine Including General Pathology, General Therapeutics, Hygiene, and the Diseases Perculiar to Women and Children, London: Longmans, Green and Co, pp. 1416-1417.

Amano, N., \& Iseki, E, (1999), “Introduction: Pick's Disease and Frontotemporal Dementia." Neuropathology, 19, pp. 417-421.

Archer, W. H. (1860), "Statistics of the Colony of Victoria 1859, etc.", In: Papers Presented to Parliament; Session 1859-60. Vol 4, Melbourne, John Ferres Government Printer.

Archer, W. H. (1862), "Statistics of the Colony of Victoria 1860, etc.", In : Papers Presented to Parliament; Session 1861-62. Vol 3. Melbourne: John Ferres Government Printer.

Archer, W. H. (1863), "Statistical register of the Colony of Victoria for the year 1861; Part VIII, Vital Statistics, etc.", In: Papers Presented to Parliament; Session 1862-63. Vol 3, Melbourne John Ferres Government Printer.

Archer, W. H. (1864), "Statistical register of the Colony of Victoria for the year 1862; Part VIII, Vital Statistics, etc.", In: Papers Presented to Parliament; Session 1864. Vol 2, Melbourne, John Ferres Government Printer.

Archer, W. H. (1865), "Statistical register of the Colony of Victoria for the year 1863; Part VIII, Vital Statistics, etc.", In: Papers Pre- 
sented to Parliament; Session 1864-65. Vol 3, Melbourne, John Ferres Government Printer.

Archer, W. H. (1866), "Statistical register of the Colony of Victoria for the year 1864; Part VIII, Vital Statistics, etc.", In: Papers Presented to Parliament; Session 1 1866. Vol 1, Melbourne, John Ferres Government Printer.

Archer, W. H. (1867), "Statistical register of the Colony of Victoria for the year 1865; Part VII, Vital Statistics, etc.", In: Papers Presented to Parliament; Session 1867. Vol 3, Melbourne, John Ferres Government Printer.

Archer, W. H. (1867), "Statistical register of the Colony of Victoria for the year 1866; Part V, Vital Statistics, etc.", In: Papers Presented to Parliament; Session 1867. Vol 5, Melbourne, John Ferres Government Printer.

Archer, W. H. (1868), "Statistical register of the Colony of Victoria for the year 1867; Part VI, Vital Statistics, etc.", In: Papers Presented to Parliament; Session 1869. Vol 3, Melbourne, John Ferres Government Printer.

Archer, W. H. (1869), "Statistical register of the Colony of Victoria for the year 1868; Part VI, Vital Statistics, etc.", In: Papers Presented to Parliament; Session 1870. Vol 4, Melbourne, John Ferres Government Printer.

Archer, W. H. (1870), "Statistical register of the Colony of Victoria for the year 1869; Part VII, Vital Statistics, etc.", In: Papers Presented to Parliament; Session 2 1870. Vol 2, Melbourne, John Ferres Government Printer.

Archer, W. H. (1872), "Statistical register of the Colony of Victoria for the year 1870; Part IX, Vital Statistics, etc.", In: Papers Presented to Parliament; Session 1872. Vol 2, Melbourne, John Ferres Government Printer.

Archer, W. H. (1872), "Statistical register of the Colony of Victoria for the year 1871; Part VII, Vital Statistics, etc.", In: Papers Presented to Parliament; Session 1872. Vol 2, Melbourne, John Ferres Government Printer.

Archer, W. H. (1874), "Statistical register of the Colony of Victoria for the year 1872; Part VIII, Vital Statistics, etc.", In: Papers Presented to Parliament; Session 1874. Vol 2, Melbourne, John Ferres Government Printer.

Arrizabalaga, J. (2002), "Problematizing Retrospective Diagnosis in the History of Disease." Asclepio, 54(1), pp. 51-70.

Baillarger, J. (1883), "Sur la Theorie de la Paralysie Generale.» Ann Med Psychol (Paris), 41, pp. 191-218.

Berrios, G. (1985), “'Depressive pseudodementia' or 'Melancholic dementia': a 19th Century view", Journal of Neurology, Neurosurgery and Psychiatry, 48, pp. 393-400.

Bonita, R., Beaglehole, R., \& Kjellstrom, T. (2006), Basic Epidemiology: 2nd Edition, Geneva, World Health Organization.

Bruce, J. M. (1882), "Debility.", In : R. Quain, A Dictionary of Medicine Including General Pathology, General Therapeutics, Hygiene and the Diseases Perculiar to Women and Children, London: Longmans, Green and Co, p. 329.
Compston, A. (1988), "The 150th anniversary of the first depiction of the lesions of multiple sclerosis." Journal of Neurology, Neurosurgery, and Psychiatry, 51, pp. 1249-1252.

Cumpston, J., \& Lewis, M. (1989), Health and Disease in Australia; A History. Canberra: Austalian Government Printing Service.

Cunningham, A. (2002), "Identifying Disease in the Past: Cutting the Gordian Knot.” Asclepio, 54(1), pp. 13-34.

Davis, G. (2008), The Cruel Madness of Love: Sex, Syphilis, and Psychiatry in Scotland, 1880-1930. Amsterdam: Rodopi.

Dawson-Butterworth, K., \& Heathcote, P. (1970), "Review of hospitalized cases of general paralysis of the insane." British Journal of Venereal Disease, 46, pp. 295-302.

Devor, E. J. (2003), “Huntington's Disease (Chorea)”, In: K. F. Kiple, The Cambridge Historical Dictionary of Disease, Cambridge: Cambridge University Press, pp. 168-169.

Fenton, J. J. (1896), "Statistical register of the Colony of Victoria for the year 1894; Part VI, Vital Statistics, etc.", In : Papers Presented to Parliament; Session 1895-96. Vol 3. Melbourne: Robt S. Brain Government Printer.

Fenton, J. J. (1896), "Statistical register of the Colony of Victoria for the year 1895; Part V, Vital Statistics, etc.", In : Papers Presented to Parliament; Session 1896. Vol 4. Melbourne: Robt S. Brain Government Printer.

Fenton, J. J. (1897), "Statistical register of the Colony of Victoria for the year 1896; Part V, Vital Statistics, etc.", In : Papers Presented to Parliament; Session 2 1897. Vol 1. Melbourne: Robt S. Brain Government Printer.

Fenton, J. J. (1898), "Statistical register of the Colony of Victoria for the year 1897; Part III, Vital Statistics, etc.", In : Papers Presented to Parliament; Session 1898. Vol 3. Melbourne: Robt S. Brain Government Printer.

Fenton, J. J. (1900), "Statistical register of the Colony of Victoria for the year 1898; Part V, Vital Statistics, etc.", In : Papers Presented to Parliament; Session 1899-1900. Vol 4. Melbourne: Robt S. Brain Government Printer.

Fenton, J. J. (1901), "Statistical register of the Colony of Victoria for the year 1899; Part V, Vital Statistics, etc.", In : Papers Presented to Parliament; Session 1900. Vol 3. Melbourne: Robt S. Brain Government Printer.

Fenton, J. J. (1901), "Statistical register of the Colony of Victoria for the year 1900; Part IV, Vital Statistics, etc.", In : Papers Presented to Parliament; Session 1901. Vol 3. Melbourne: Robt S. Brain Government Printer.

Fraser, I. (1981), "General paralysis of the Insane." British Medical Journal, 283, pp. 1631-1632.

Galbraith, A. (1938), "Some problems in the histopathology of general paralysis of the insane." British Journal of Venereal Disease, 14 , pp. $197-216$.

Grant, D. (1897), "Some Illustrations of General Paralysis of the Insane, as seen in Private Practice.", Intercolonial Medical Journal of Australasia, 2(4), pp. 157-166. 
Greenblatt, S. H. (2003), "Harvey Cushing's Paradigmatic Contribution to Neurosurgery and the Evolution of His Thoughts about Specialization." Bulletin of the History of Medicine, 4, pp. 789-822.

Hayter, H. H. (1874), "Statistical register of the Colony of Victoria for the year 1873; Part VIII, Vital Statistics, etc.", In : Papers Presented to Parliament; Session 1874. Vol 3. Melbourne: John Ferres Government Printer.

Hayter, H. H. (1875), "Statistical register of the Colony of Victoria for the year 1874; Part VIII, Vital Statistics, etc.", In : Papers Presented to Parliament; Session 1875-76. Vol 3. Melbourne: John Ferres Government Printer.

Hayter, H. H. (1876), "Statistical register of the Colony of Victoria for the year 1875; Part VIII, Vital Statistics, etc.", In : Papers Presented to Parliament; Session 1876. Vol 3. Melbourne: John Ferres Government Printer.

Hayter, H. H. (1878), "Statistical register of the Colony of Victoria for the year 1877; Part V, Vital Statistics, etc.", In: Papers Presented to Parliament; Session 1878. Vol 2. Melbourne: John Ferres Government Printer.

Hayter, H. H. (1880), "Statistical register of the Colony of Victoria for the year 1879; Part IV, Vital Statistics, etc.", In: Papers Presented to Parliament; Session 1880-81. Vol 3. Melbourne: John Ferres Government Printer.

Hayter, H. H. (1881), "Statistical register of the Colony of Victoria for the year 1880; Part III, Vital Statistics, etc.", In : Papers Presented to Parliament; Session 1881. Vol 3. Melbourne: John Ferres Government Printer.

Hayter, H. H. (1883), "Statistical register of the Colony of Victoria for the year 1881; Part IV, Vital Statistics etc.", In: Papers Presented to Parliament; Session 1882-83. Vol 3. Melbourne: John Ferres Government Printer.

Hayter, H. H. (1883), "Statistical register of the Colony of Victoria for the year 1882; Part IV, Vital Statistics, etc.", In: Papers Presented to Parliament; Session 2, 1883. Vol 3. Melbourne: John Ferres Government Printer.

Hayter, H. H. (1884), "Statistical register of the Colony of Victoria for the year 1883; Part V, Vital Statistics, etc.", In: Papers Presented to Parliament; Session 1884. Vol 4. Melbourne: John Ferres Government Printer.

Hayter, H. H. (1885), "Statistical register of the Colony of Victoria for the year 1884; Part IV, Vital Statistics, etc.", In: Papers Presented to Parliament; Session 1885. Vol 3. Melbourne: Robt S. Brain Government Printer.

Hayter, H. H. (1886), "Statistical register of the Colony of Victoria for the year 1885; Part IV, Vital Statistics, etc.", In: Papers Presented to Parliament; Session 1886. Vol 3. Melbourne: Robt S. Brain Government Printer.

Hayter, H. H. (1887), "Statistical register of the Colony of Victoria for the year 1886; Part IV, Vital Statistics, etc.", In: Papers Presented to Parliament; Session 1887. Vol 3. Melbourne: Robt S. Brain Government Printer.

Hayter, H. H. (1888), "Statistical register of the Colony of Victoria for the year 1887; Part IV, Vital Statistics, etc.", In: Papers Presented to Parliament; Session 1888. Vol 3. Melbourne: Robt S. Brain Government Printer.

Hayter, H. H. (1889), "Statistical register of the Colony of Victoria for the year 1888; Part V, Vital Statistics, etc.", In: Papers Presented to Parliament; Session 1889. Vol 3. Melbourne: Robt S. Brain Government Printer.

Hayter, H. H. (1890), "Statistical register of the Colony of Victoria for the year 1889; Part VII, Vital Statistics, etc.", In: Papers Presented to Parliament; Session 1890. Vol 4. Melbourne: Robt S. Brain Government Printer.

Hayter, H. H. (1891), "Statistical register of the Colony of Victoria for the year 1890; Part IV, Vital Statistics, etc.", In: Papers Presented to Parliament; Session 1891. Vol 5. Melbourne: Robt S. Brain Government Printer.

Hayter, H. H. (1893), "Statistical register of the Colony of Victoria for the year 1891; Part V, Vital Statistics, etc.", In: Papers Presented to Parliament; Session 1892-93. Vol 5. Melbourne: Robt S. Brain Government Printer.

Hayter, H. H. (1893), "Statistical register of the Colony of Victoria for the year 1892; Part VI, Vital Statistics, etc.", In: Papers Presented to Parliament; Session 1893. Vol 2. Melbourne: Robt S. Brain Government Printer.

Hayter, H. H. (1895), "Statistical register of the Colony of Victoria for the year 1893; Part V, Vital Statistics, etc.", In: Papers Presented to Parliament; Session 1894-95. Vol 2. Melbourne: Robt S. Brain Government Printer.

Hendren, H. A. (1879), "Statistical register of the Colony of Victoria for the year 1878; Part IV, Vital Statistics, etc.", In: Papers Presented to Parliament; Session 1879-80. Vol 2. Melbourne: John Ferres Government Printer.

Hirshbein, L. D. (2009), "Gender, Age, and Diagnosis: The Rise and Fall of Involutional Melancholia in American Psychiatry." 19001980. Bulletin of the History of Medicine, 83(4), pp. 710-745

Kiple, K. F. (2003), “Alzheimer's Disease.”, In: K. F. Kiple, The Cambridge Historical Dictionary of Disease, Cambridge: Cambridge University Press, pp. 14-19.

Kraepelin, E. (1904), "Lecture XX: Final stages of general paralysis of the insane.", In: E. Kraepelin, Lectures on clinical psychiatry, New York: William Wood \& Co, pp. 190-199.

Lewis, M. (1998), "Thorns on the Rose: The History of Sexually Transmitted Diseases in Australia in International Perspective." Canberra: Australian Government Publishing Service.

BIBLIOGRAPHY \I 3081 Lynch, M. (2002), Mining in World History. London: Reaktion Books.

Malcolm, E. (2009), "Asylum Architecture through German Eyes: Kew, Melbourne, 1867." Health and History, 11(1), pp. 46-64.

Nicol, W. (1956), "General Paralysis of the Insane." British Journal of Venereal Disease, 32, pp. 9-16.

Office of the Government Printer. (1916), "Statistical Register of the State of Victoria for the Year 1915: Part VII Vital Statisitics, Etc.", In: Papers Presented to Parliament. Melbourne: Albert J. Mullett, Government Printer. 
Office of the Government Statisit. (1908), "Statistical Register of the State of Victoria for the Year 1907: Part VII Vital Statistics, Etc.", In: Papers Presented to Parliament. Melbourne: J. Kemp. Government Printer.

Office of the Government Statist. (1904), "Statistical Register of the State of Victoria for the Year 1903: Part V. Vital Statistics Etc.", In: Papers Presented to Parliament 1904. Melbourne: Robt. S. Brain, Government Printer.

Office of the Government Statist. (1905), "Statistical Register of the State of Victoria for the Year 1904: Part VII Vital Statistics, Etc.", In: Papers Presented to Parliament. Melbourne: Robt. S. Brain, Government Printer.

Office of the Government Statist. (1906), "Statistical Register of the State of Victoria for the Year 1905: Part VII. Vital Statisitics.", In: Papers Presented to Parliament. Melbourne: J. Kemp, Government Printer

Office of the Government Statist. (1907), "Statistical Register of the State of Victoria for the Year 1906: Part VII: Vital Statistics.", In: Papers Presented to Parliament. Melbourne: J. Kemp, Government Printer.

Office of the Government Statist. (1909), "Statistical Register of the State of Victoria for the Year 1908: Part VII Vital Statisitics, Etc.", In: Papers Presented to Parliament. Melbourne: J. Kemp, Government Printer.

Office of the Government Statist. (1910), "Statistical Register of the State of Victoria for the Year 1909, Part VII Vital Statistics, Etc.", In: Papers Presented to Parliament. Melbourne: J. Kemp, Government Printer.

Office of the Government Statist. (1911), "Statistical Register for the State of Victoria for the Year 1910: Part VII Vital Statistics, Etc.", In: Papers Presented to Parliament. Melbourne: J. Kemp, Government Printer.

Office of the Government Statist. (1913), "Statistical Register for the State of Victoria for the Year 1911: Part VII Vital Statistics, Etc.", In: Papers Presented to Parliament. Melbourne: Albert J. Mullett, Government Printer.

Office of the Government Statist. (1913), "Statistical Register for the State of Victoria for the Year 1912: Part VII Vital Statisitics, Etc.", In: Papers Presented to Parliament. Melbourne: Albert J. Mullett, Government Printer.

Office of the Government Statist. (1914), "Statistical Register for the State of Victoria for the Year 1913: Part VII Vital Statisitics, Etc.", In: Papers Presented to Parliament. Melbourne: Albert J. Mullett, Government Printer.

Office of the Government Statist. (1915), "Statistical Register for the State of Victoria for the Year 1914: Part VII Vital Statisitics, Etc.",
In: Papers Presented to Parliament. Melbourne: Albert J. Mullett, Government Printer.

Office of the Government Statist. (1917-18), "Statistical Register of the State of Victoria for the Year 1916: Part VI Vital Statistics.", In: Papers Presented to Parliament. Melbourne: Albert J. Mullett, Government Printer.

O'Shea, J. (1990)," 'Two minutes with venus, two years with mercury'--mercury as an antisyphilitic chemotherapeutic agent." Journal of the Royal Society of Medicine, 83(6), pp. 392-395.

Pasamanick, B. (1959), Epidemiology of Mental Disorder. Washington: American Association for the Advancement of Science.

Patten, B. M. (2003), “Parkinson's Disease (Parkinsonism),", In: K. F. Kiple, The Cambridge Historical Dictionary of Disease, Cambridge: Cambridge University Press, pp. 240-241.

Peset, J. L. (2002), "The History of Disease: Introduction." Asclepio, 54(1), pp. 7-12.

Poirier, J., \& Derouesne, C. (2003), "Apoplexy and Stroke.", In: K. F. Kiple, The Cambridge Historical Dictionary of Disease, Cambridge: Cambridge University Press, pp. 31-34.

Quain, R. (1882), A Dictionary of Medicine Including General Pathology, General Therapeutics, Hygiene, and the Diseases Peculiar to Women and Children. London: Longmans, Green and Co.

Roberts, P. (2013), A Rose By Any Other Name: Historical Epidemiology in Late Colonial and Early Modern Victoria (1853-c.1930), Canberra: A Thesis Submitted for partial fulfilment of the Degree of Doctor of Philosophy of the Australian National University.

Sibbald, J. (1882), "General Paralysis of the Insane.", In: R. Quain, A Dictionary of Medicine: Including General Pathology, Generl Therapeutics, Hygiene, and the Diseases Peculiar to Women and Children, London: Longmans, Green, and Co, pp. 531-532.

Smith, P. (1873, February), "On Premonitory Symptoms of Insanity." Australian Medical Journal, 18, pp. 39-45.

Smith, P. (1874, January), "Hints on the giving of Lunacy Certificates." Australian Medical Journal, 19, pp. 14-19.

Tedebrand, L.-G. (2002), "Comments on the Round Table the History of Disease." Asclepio, 54(1), pp. 93-96.

Tighe, J. A. (2005), "'What's in a Name?': A Brief Foray into the History of Insanity in England and the United States." The Journal of the American Academy of Psychiatry and the Law, 33, pp. 252-258.

Wickman, P. (2006), "Idiocy in Virginia, 1616-1860." Bulletin of the History of Medicine, 80(4), pp. 677-701. 